\title{
ELECTRICAL CONDUCTIVITY IN Piptadenia moniliformis Benth. SEED LOTS CLASSIFIED BY SIZE AND COLOR ${ }^{1}$
}

\author{
Gilvaneide Alves Azeredo ${ }^{2 *}$, Rinaldo César de Paula ${ }^{3}$ and Sérgio Valiengo Valeri ${ }^{4}$
}

\footnotetext{
${ }^{1}$ Received on 21.02.2013 accepted for publication on 19.08.2016.

${ }^{2}$ Universidade Federal da Paraíba, Centro de Ciências Humanas, Sociais e Agrárias, Bananeiras, PB - Brasil. E-mail: <azeredogil@yahoo.com.br>.

${ }^{3}$ Universidade Estadual Paulista Júlio de Mesquita Filho, Faculdade de Ciências Agrárias e Veterinárias de Jaboticabal, Departamento de Produção Vegetal, Jaboticabal, SP - Brasil. E-mail: <rcpaula@fcav.unesp.br>.

${ }^{4}$ Universidade Estadual Paulista Júlio de Mesquita Filho, Faculdade de Ciências Agrárias e Veterinárias de Jaboticabal, Departamento de Produção Vegetal, Jaboticabal, SP - Brasil. E-mail: <valeri@fcav.unesp.br>.

*Corresponding author.
}

\begin{abstract}
Among the most widely used tests for evaluating seed vigor, electrical conductivity (EC) stands out as one of the most promising due to its speed and simplicity. This study aimed to verify if the EC test could be used to evaluate the physiological quality of seed lots of Piptadenia moniliformis Benth. A seed lot, which was classified by seed tegument color and size, was used based on seed retention in round-hole screens, sizes 11 and 15, constituting 10 sub-lots. Prior to germination and the EC test, the seeds were immersed in concentrated sulfuric acid for 20 minutes in order to overcome tegument dormancy. During the EC test, we soaked seeds in $75 \mathrm{~mL}$ of water at $25^{\circ} \mathrm{C}$ and tested eight soaking periods $(2,4,6,24,48,72,96$, and $120 \mathrm{~h}$ ) and two seed quantities (25 and 50) per replicate. The EC test, regardless of the number of seeds or soaking period, was not adequate for evaluating the physiological quality of color- or size-classified seed lots from P. moniliformis Benth. .
\end{abstract}

Keywords: Vigor; Forest seeds; Rapid Tests.

\section{CONDUTIVIDADE ELÉTRICA EM LOTES DE SEMENTES DE Piptadenia moniliformis Benth. CLASSIFICADAS POR TAMANHO E COLORAÇÃO}

RESUMO - Entre os testes mais utilizados para a avaliação do vigor de sementes, o de condutividade elétrica (CE) se destaca como um dos mais promissores, pela sua rapidez e simplicidade. O presente trabalho teve por objetivo verificar a aplicabilidade do teste de CE na avaliação da qualidade fisiológica de lotes de sementes de Piptadenia moniliformis Benth. Foi usado um lote de sementes classificado quanto à coloração do tegumento e tamanho das sementes, com base na retenção das mesmas em peneiras de furos redondos de tamanhos 11 a 15, constituindo, assim, 10 sub-lotes. Antes da realização do teste de germinação e de CE, as sementes foram imersas em ácido sulfúrico concentrado por 20 minutos, visando superar a dormência tegumentar. No teste de CE, testaram-se oito períodos de embebição (2, 4, 6, 24, 48, 72, 96 e 120 h) e duas quantidades de sementes (25 e 50) por repetição, embebidas em $75 \mathrm{~mL}$ de água a $25^{\circ} \mathrm{C}$. O teste de condutividade elétrica, independentemente do número de sementes e período de embebição não foi adequado para a avaliação da qualidade fisiológica de lotes de sementes de P. moniliformis Benth. classificados pela coloração e, ou tamanho das sementes.

Palavras-chave: Vigor; Sementes florestais; Testes rápidos. 


\section{INTRODUCTION}

After physiological maturity, seeds begin to suffer continuous and irreversible deterioration. Understanding this process has become increasingly important because it is through this process that research has developed methods to determine the physiological potential and vigor of seed lots (CUSTÓDIO, 2005).

Standard germination tests have limitations and do not reveal subtle differences between seed lots. They have a long turnaround time, which is increasingly important to improving the tests for evaluation of seed vigor especially with regard to obtaining consistent and quick information(TORRES, 2005). For a more precise analysis of seed quality, it is necessary to supplement the information provided by the germination tests with vigor tests. This allows one to select the best lots for marketing and sowing (ARAÚJO et al., 2011).

The technical and scientific knowledge on forest species is essential for actions inherent to the establishment of forest plantation, particularly in areas of ecological restoration (DUTRA et al., 2007). This ensures adequate plant populations across a wide range of environmental conditions. This consequently allows the maximum potential expression of the cultivar in question. The use of high quality seeds is an essential component of any cultivation system (BARBOSA et al., 2012).

Vigor in a seed lot is not determined by one characteristic in particular, but by a set of characteristics associated with the performance of the seeds (PERRY, 1981). It seems unlikely that a single test whether germinative, physiological or biochemical is appropriate under all conditions even for a single species (MARCOS FILHO, 2005).

A vigor test must record seed quality indexes more sensitively than the germination test. It must also separate seed lots in terms of performance potential and be objective, fast, simple, economically viable, reproducible, and objectively interpretable (HAMPTON; COOLBEAR, 1990).

In seeds with high commercial value, vigor information is even more important because seed companies require quick decisions regarding management during harvesting, receiving, processing, storage, and marketing. Accordingly, there is a need to reduce the period for evaluating physiological quality in seeds.
This is considered a priority for research (MARCOS FILHO, 2005).

The use of any non-traditional species for plantations with production and/or environmental purposes requires the development of appropriate production technology beginning with knowledge on seed quality (ARAUJO et al., 2011). For forest species, the evaluation of seed quality through vigor testing is very important for the storage and production of seedlings because seed quality directly influences the establishment of forest plantations whether they have success or not in forestation or reforestation programs (PIÑA-RODRIGUES, 1988).

Thus, evaluating seed physiological quality allows the estimation and comparison of seed lots. Differences between mother plants, progenies and origins can be identified. This offers researchers additional data at early stages of genetic improvement or conservation programs (PIÑA-RODRIGUES; VALENTINI, 1995).

Among the most widely used tests for evaluating seed vigor is electrical conductivity (EC). This is one of the most promising elements for its speed and simplicity. It consists of indirectly assessing the degree of cell membrane structure due to the seed's deterioration by determining the amount of leached ions in a soaking solution. The seeds are soaked in a given volume of distilled water under a controlled temperature for a predetermined period. Seeds with lower physiological potential release greater amounts of leachates because their membranes are less complex in terms of structure and selectivity (TORRES, 2002).

The test is promising in terms of standardization, but studies conducted by the Vigor Committee of ISTA (PERRY, 1981) found variations in results due to methodological problems. Studies have shown that several factors can affect the outcome of this test genotype, seed moisture content, seed size, water volume, and sample size (VIEIRA; KRZYZANOWSKI, 1999).

Studies conducted with different tree species have shown that the decrease in germination and vigor is directly proportional to the increase in solute leaching. Electrical conductivity (EC) is an efficient method for evaluating vigor (CUSTÓDIO, 2005). For example, different lots of seeds from Sebastiania commersoniana (Baill) were differentiated via the EC test at $25^{\circ} \mathrm{C}$ using 75 seeds soaked in $75 \mathrm{ml}$ of water for 24 hours. This 
was a promising test in the evaluation of seed vigor (SANTOS; PAULA, 2005). For Dalbergia nigra (Vell.) Fr. All. Ex. Benth (Fabaceae) at the same temperature, the recommended duration was 30 or 36 hours (MARQUES et al., 2002a).

The EC test is good at evaluating vigor and provides consistent results and identifies differences in the seeds' physiological potential. However, its use for forest seeds is still restricted. This motivates our research into more specific procedures. Here, we verified the applicability of the EC test in the evaluation of a physiological quality of seed lots from $P$. moniliformis Benth. (Fabaceae). The samples were classified by seed size and color, and we then assessed the effect of the number of seeds and soaking time on leaching.

\section{MATERIALS AND METHODS}

This study was developed in the Laboratory of Seed and Forest Improvement of Unesp/Jaboticabal, Jaboticabal - SP, with seeds collected from different mother trees in the municipality of Campo Grande do Piauí - PI. The seeds were then sent to UNESP-Jaboticabal and were stored in paper in a cold chamber $\left(8 \pm 2{ }^{\circ} \mathrm{C}\right.$, $60 \pm 5 \%$ UR) until the experiment was conducted in October of 2007.

The seeds were non-uniform in color and size, and were first separated by tegument color into light (L) and dark (D). Subsequently, the seeds were classified by size using sieves $(\mathrm{S})$ with round holes $11,12,13$, 14 and 15 according to the seed retention. Accordingly, $10 \mathrm{sub}$-lots were established resulting in a combination of the two colors and five size classes: S11L, S11D, S12L, S12D, S13L, S13D, S14L, S14D, S15L and S15D.

Prior to the germination and electrical conductivity tests (EC), the seeds were immersed in concentrated sulfuric acid for 20 minutes to overcome tegument dormancy. Afterwards, the following characteristics were evaluated: 1) Water content was measured in an incubator at $105 \pm 3{ }^{\circ} \mathrm{C} / 24 \mathrm{~h}$ (BRASIL, 2009) using two replicates of 20 seeds per treatment; 2) The germination test was conducted at $25{ }^{\circ} \mathrm{C}$ with a photoperiod of 8 hours and four replicates of 25 seeds. These were distributed into transparent plastic (with dimensions of $11 \times 11 \times 3 \mathrm{~cm}$ ). Seeds were placed between filter paper with two sheets at the base and one over the seeds. The seeds were moistened with water equivalent to 2.5 times the mass of the non-hydrated paper
(GONZALES et al., 2009). The criteria used for seed germination was the primary root emission with a length equal to or greater than $1 \mathrm{~mm}$. The germination test had duration of 21 days or until it stabilized. We obtained a germination speed index, and there was a daily count of the number of seeds emitting a root to the previously mentioned length following the formula proposed by Maguire (1962). The first count was done together with the germination test, and this occurred on the second day after sowing.

The electrical conductivity test (CE) used eight soaking periods $(2,4,6,24,48,72,96$ and $120 \mathrm{~h})$ and two seed quantities ( 25 and 50 ) per replicate. The four replicates of each seed quantity were weighed on an electronic scale with a precision of $0.001 \mathrm{~g}$, soaked in $75 \mathrm{~mL}$ of distilled water in plastic cups $(180 \mathrm{~mL})$, and maintained in a chamber of Biochemical Oxygen Demand (B.O.D) at a temperature of $25^{\circ} \mathrm{C}$ (PINHO et al., 2009). After each soaking period, the electrical conductivity of the solution was determined using a conductivity meter DIGIMED CD-21 and the results were expressed in $\mu \mathrm{s} \mathrm{cm}^{-1} \mathrm{~g}^{-1}$ seed.

The germination data, first count, and germination speed index were analyzed in a completely randomized design that used analysis of variance for each color. The data were expressed as a percentage and were submitted to a Lilliefors normality test. They did not present a normal distribution, and therefore were transformed using arcoseno $(\mathrm{G} / 100)^{0.5}$. The treatment's averages were compared using a Tukey test at 5\% probability.

The EC data were submitted to an analysis of variance separately for each sample size ( 25 or 50 seeds) according to the completely randomized design in a factorial scheme $5 \times 2 \times 8$ ( 5 sizes $\times 2$ colors $\times 8$ soaking periods). The treatment averages were compared using a Tukey test at $5 \%$ probability. The behavior of each treatment resulting from the combination color $\mathrm{x}$ seed size was analyzed for each seed quantity during the soaking periods using a polynomial regression to the third order. The highest order equation with statistical significance of $5 \%$ via an $\mathrm{F}$ test was selected for further study.

\section{RESULTS}

The initial water content of seeds belonging to different sub-lots ranged from 11 to $13 \%$. In terms of viability and initial vigor, the seeds retained in the size

Revista Árvore, Viçosa-MG, v.40, n.5, p.855-866, 2016

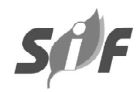


14 sieve (light colored) showed a higher percentage and first count of germination. They differed from those retained in the size 13 sieve and were equal to the seeds retained in the other sieves. For dark seeds, the first count showed similar behavior as previously stated. There were higher values of germination for size 14 seeds, and these differed only from the sieve 13 . No significant differences were observed between IGS sub-lots (light and dark color) and germination (dark color) (Table 1).

There was a significant effect for all interactions in the electrical conductivity test (EC) of $P$. moniliformis seed sub-lots considering both seed quantities (Table 2). Even when not statistically significant, the light seeds in both sample sizes released the largest amount of leachates. This suggested that they were less vigorous than the dark seeds except for seeds from sieve 13 when using 50 seeds/replication (Table 3 ).

The samples that used 25 light colored seeds in sieves 14 and 13 leached greater quantities of solutes. They did not differ between each other. Similarly, the latter did not differ from seeds in sieve 15. The dark colored seeds from sieves 13, 14 and 15 had higher values of EC than seeds from sieves 11 and 12 . With 50 seeds/ sample, the light colored seeds retained in sieves 14 and 15 and the dark colored seeds in sieve 13 had less vigor (Table 3 ).
When using 25 seeds per replicate, the separation of light colored sub-lots occurs at 72 hours of soaking. The seeds retained in sieve 13 have higher values of EC and differ only from those retained in sieves 11 and 12 (greater vigor). After 96 hours of soaking, there is a formation of two classes of vigor. That is, seeds retained in sieves 11 and 12 with higher vigor as well as seeds with lower vigor. After 120 hours, seeds were stratified into three classes: seeds from sieves 11 and 12 had higher vigor, sieves 14 and 15 had less vigor, and those from sieve 13 had an intermediate behavior. Importantly, seeds from sieve 13 had lower quality in terms of percentage and first count of germination (Table 1). This was not consistent with the EC test (Table 4).

The behavior as a function of seed size was different for dark seeds (Table 4). With two hours of soaking, there was already some distinction between sub-lots indicating seeds from sieves 11 and 12 as having the best quality. This had the smallest EC values during soaking. In general, the seeds from sieves 13, 14 and 15 had the most leachates. Similarly to the light colored seeds, sub-lots ordering occurred only after 120 hours. They could then be classified as superior (seeds retained from sieves 11 and 12), intermediate (seeds retained in sieves 14 and 15) and inferior (seeds retained in sieve 13). The initial characterization results (first count) of these seeds (Table 1) partially comply with

Table 1 - Water content (WC, \%), germination $\left(\mathrm{G}\right.$, arcoseno $\left.(\mathrm{G} / 100)^{0.5}\right)$, first counting $\left(\mathrm{FC}\right.$, $\left.\operatorname{arcoseno}(\mathrm{FC} / 100)^{0.5}\right)$ and index of germination speed (IGS) of different seed sub-lots of Piptadenia moniliformis Benth., classified by seed color and size.

Tabela 1 - Teor de água (WC, \%), germinação $\left(G\right.$, arcoseno $\left.(G / 100)^{0.5}\right)$, primeira contagem $\left(F C\right.$, arcoseno $\left.(F C / 100)^{0.5}\right)$ e indice de velocidade de germinação (IGS) de diferentes sub-lotes de sementes Piptadenia moniliformis Benth., classificados quanto a coloração e tamanho das sementes.

\begin{tabular}{|c|c|c|c|c|}
\hline Size (Sieves) & WC (\%) & $\mathrm{G}$ & IGS & FC \\
\hline & \multicolumn{4}{|c|}{ Light Seeds } \\
\hline S11 & 11 & $82 \mathrm{ab}$ & $9.8 \mathrm{a}$ & $66 \mathrm{ab}$ \\
\hline $\mathrm{S} 12$ & 12 & $78 \mathrm{ab}$ & $9.0 \mathrm{a}$ & $63 \mathrm{ab}$ \\
\hline S13 & 12 & $65 \mathrm{~b}$ & $8.2 \mathrm{a}$ & $60 \mathrm{~b}$ \\
\hline S14 & 13 & $87 \mathrm{a}$ & $10.7 \mathrm{a}$ & $76 \mathrm{a}$ \\
\hline S15 & 13 & $77 \mathrm{ab}$ & $9.6 \mathrm{a}$ & $72 \mathrm{ab}$ \\
\hline \multirow[t]{2}{*}{$\mathrm{CV}(\%)=$} & - & 9.62 & 20.93 & 11.02 \\
\hline & \multicolumn{4}{|c|}{ Dark Seeds } \\
\hline $\mathrm{S} 11$ & 11 & $73 \mathrm{a}$ & $8.4 \mathrm{a}$ & $62 \mathrm{ab}$ \\
\hline $\mathrm{S} 12$ & 11 & $78 \mathrm{a}$ & $9.8 \mathrm{a}$ & $70 \mathrm{ab}$ \\
\hline $\mathrm{S} 13$ & 13 & $71 \mathrm{a}$ & $8.7 \mathrm{a}$ & $59 \quad$ b \\
\hline S14 & 13 & $80 \mathrm{a}$ & $9.8 \mathrm{a}$ & $75 \mathrm{a}$ \\
\hline S15 & 13 & $76 \mathrm{a}$ & $9.9 \mathrm{a}$ & $73 \mathrm{ab}$ \\
\hline $\mathrm{CV}(\%)=$ & - & 10.23 & 22.80 & 10.49 \\
\hline
\end{tabular}

Means followed by the same letter for each color and characteristic did not differ by the Tukey test $(\mathrm{P}>0.05)$.

Médias seguidas por uma mesma letra, para cada coloração e característica, não diferem pelo teste Tukey (P>0,05).

Revista Árvore, Viçosa-MG, v.40, n.5, p.855-866, 2016 
Table 2 - Summary of the analysis of variance for the electrical conductivity of Piptadenia moniliformis Benth. seeds, separated by seed coloration and size, using samples of 25 and 50 seeds soaked in $75 \mathrm{~mL}$ of distilled water for different time periods.

Tabela 2 - Resumo da análise de variância para a condutividade elétrica de sementes de Piptadenia moniliformis Benth., separadas quanto a coloração e tamanho das sementes, utilizando amostras de 25 e 50 sementes, embebidas em $75 \mathrm{~mL}$ de água destilada por diferentes periodos.

\begin{tabular}{lcc}
\hline Sources of & \multicolumn{2}{c}{ Mean Squares } \\
\cline { 2 - 3 } Variation & 25 seeds & 50 seeds \\
\hline Treatments & 30404.65 & 23860.60 \\
Size (T) & $72858.98^{* *}$ & $57978.57^{* *}$ \\
Color (C) & $166762.19^{* *}$ & $6188.33^{* *}$ \\
Period (P) & $163286.15^{* *}$ & $163283.44^{* *}$ \\
T X C & $13138.23^{* *}$ & $13611.39^{* *}$ \\
T XP & $9247.65^{* *}$ & $7520.24^{* *}$ \\
C X P & $36998.81^{* *}$ & $6854.96^{* *}$ \\
RESIDUE & 1593.43 & 594.500 \\
\hline Mean & 166.43 & 149.67 \\
CV $(\%)=$ & 23.98 & 16.79 \\
\hline
\end{tabular}

**-significant at $1 \%$ probability, by the F-test.

**-significativo a $1 \%$ de probabilidade, pelo teste $F$

Table 3 - Electrical conductivity of Piptadenia moniliformis Benth. seeds, classified by color and size, using samples of 25 and 50 seeds soaked in $75 \mathrm{~mL}$ of water at $25^{\circ} \mathrm{C}$ (averages from different periods of soaking).

Tabela 3 - Condutividade elétrica $\left(\mu \mathrm{sm}^{-1} \mathrm{~g}^{-1}\right)$ de sementes de Piptadenia moniliformis Benth., classificadas quanto a coloração e tamanho, utilizando amostras de 25 e 50 sementes embebidas em $75 \mathrm{~mL}$ de água a $25^{\circ} \mathrm{C}$. (Médias de diferentes períodos de embebição).

\begin{tabular}{cccr}
\hline Size & Light & Dark & Means \\
\cline { 2 - 3 } & \multicolumn{2}{c}{25 seeds } & 125.06 \\
\hline S11 & $130.36 \mathrm{Ac}$ & $119.75 \mathrm{Ab}$ & 135.51 \\
S12 & $146.29 \mathrm{Ac}$ & $124.73 \mathrm{Bb}$ & 189.88 \\
S13 & $220.09 \mathrm{Aab}$ & $159.66 \mathrm{Ba}$ & 199.33 \\
S14 & $239.09 \mathrm{Aa}$ & $159.56 \mathrm{Ba}$ & 182.38 \\
S15 & $210.45 \mathrm{Ab}$ & $154.30 \mathrm{Ba}$ & \\
\hline Means & 189.26 & 50 seeds & 143.60 \\
\hline & & & 110.87 \\
\hline S11 & $114.47 \mathrm{Ac}$ & $107.28 \mathrm{Ac}$ & 123.48 \\
S12 & $127.11 \mathrm{Ac}$ & $190.11 \mathrm{Aa}$ & 171.24 \\
S13 & $152.38 \mathrm{Bb}$ & $151.10 \mathrm{Bb}$ & 167.88 \\
S14 & $184.66 \mathrm{Aa}$ & $158.03 \mathrm{Bb}$ & 174.88 \\
S15 & $191.73 \mathrm{Aa}$ & 145.48 & \\
\hline Means & 154.07 & & \\
\hline
\end{tabular}

Means followed by the same capital letter in line and lowercase in the column do not differ between each other at $5 \%$ probability by the Tukey test.

Médias seguidas pela mesma letra maiúscula na linha e minúscula na coluna não diferem entre si a $5 \%$ de probabilidade pelo teste de Tukey.

the EC results (Table 4) indicating that seeds from sieve 13 were low vigor. The other sub-lots had little differences in the germination test. However, in terms of absolute values, there is an inversion of the results with those from the EC.

Some results were similar with 50 seeds per test as those obtained with 25 seeds (Table 4). For light seeds, the behavior was practically identical.
Differentiation of sub-lots occurred after 72 hours. Seeds from sieves 14 and 15 expressed low vigor and seeds from sieves 11 and 12 expressing high vigor. After 96 hours of soaking, there was a greater discrimination of sub-lots with seeds retained in sieve 13 showing an intermediate behavior. Those from sieves 11 and 12 are high quality, and those from sieves 14 and 15 were low quality.

Revista Árvore, Viçosa-MG, v.40, n.5, p.855-866, 2016 
Table 4 - Electrical conductivity of different sub-lots of Piptadenia moniliformis Benth. seeds using samples of 25 and 50 seeds soaked in $75 \mathrm{~mL}$ of distilled water at $25^{\circ} \mathrm{C}$ for different periods.

Tabela 4 - Condutividade elétrica ( $\mu \mathrm{s} \mathrm{cm-1g-1)} \mathrm{de} \mathrm{diferentes} \mathrm{sub-lotes} \mathrm{de} \mathrm{sementes} \mathrm{de} \mathrm{Piptadenia} \mathrm{moniliformis} \mathrm{Benth.} \mathrm{em}$ amostras de 25 e 50 sementes embebidas em $75 \mathrm{~mL}$ de água destilada, a $25^{\circ} \mathrm{C}$, por diferentes períodos.

\begin{tabular}{|c|c|c|c|c|c|c|c|c|c|}
\hline \multirow[t]{2}{*}{ Size } & \multicolumn{9}{|c|}{ Soaking periods (hours) } \\
\hline & 2 & 4 & 6 & 24 & 48 & 72 & 96 & 120 & Means \\
\hline & \multicolumn{9}{|c|}{ Light seeds -25 seeds } \\
\hline S11 & $75.45 \mathrm{a}$ & $105.53 \mathrm{a}$ & $107.34 \mathrm{a}$ & $133.43 \mathrm{a}$ & $139.61 \mathrm{a}$ & $148.92 \mathrm{c}$ & $157.54 \mathrm{~b}$ & $175.06 \mathrm{c}$ & 130.36 \\
\hline $\mathrm{S} 12$ & $78.75 \mathrm{a}$ & $112.03 \mathrm{a}$ & $118.05 \mathrm{a}$ & $151.58 \mathrm{a}$ & $165.54 \mathrm{a}$ & $171.22 \mathrm{bc}$ & $178.24 \mathrm{~b}$ & $195.10 \mathrm{c}$ & 146.31 \\
\hline S13 & $92.89 \mathrm{a}$ & $127.65 \mathrm{a}$ & $138.75 \mathrm{a}$ & $185.88 \mathrm{a}$ & $207.75 \mathrm{a}$ & $282.01 \mathrm{a}$ & $332.04 \mathrm{a}$ & $393.72 \mathrm{~b}$ & 220.08 \\
\hline S14 & $101.89 \mathrm{a}$ & $123.60 \mathrm{a}$ & $125.75 \mathrm{a}$ & $155.63 \mathrm{a}$ & $185.08 \mathrm{a}$ & $254.94 \mathrm{ab}$ & $397.98 \mathrm{a}$ & $567.88 \mathrm{a}$ & 239.09 \\
\hline S15 & $105.80 \mathrm{a}$ & $122.83 \mathrm{a}$ & $125.30 \mathrm{a}$ & $140.29 \mathrm{a}$ & $158.38 \mathrm{a}$ & $206.05 \mathrm{abc}$ & $303.24 \mathrm{a}$ & $521.72 \mathrm{a}$ & 336.72 \\
\hline Means & 90.95 & 118.32 & 123.03 & 153.36 & 171.27 & 212.62 & 273.20 & 370.69 & \\
\hline
\end{tabular}

$\mathrm{CV}(\%)=28$

\begin{tabular}{|c|c|c|c|c|c|c|c|c|c|}
\hline \multirow[b]{2}{*}{ S11 } & \multicolumn{9}{|c|}{ Dark seeds -25 seeds } \\
\hline & $70.01 \mathrm{~b}$ & $96.97 \mathrm{~b}$ & $101.73 \mathrm{~b}$ & $121.17 \mathrm{~b}$ & $124.12 \mathrm{~b}$ & $133.79 \mathrm{c}$ & $145.35 \mathrm{~b}$ & $164.90 \mathrm{c}$ & 119.75 \\
\hline $\mathrm{S} 12$ & $69.29 \mathrm{~b}$ & $97.80 \mathrm{~b}$ & $101.12 \mathrm{~b}$ & $127.30 \mathrm{ab}$ & $136.91 \mathrm{ab}$ & $143.76 \mathrm{bc}$ & $154.34 \mathrm{~b}$ & $167.07 \mathrm{c}$ & 124.69 \\
\hline $\mathrm{S} 13$ & $89.77 \mathrm{ab}$ & $110.45 \mathrm{ab}$ & $116.51 \mathrm{ab}$ & $151.46 \mathrm{ab}$ & $161.63 \mathrm{a}$ & $183.61 \mathrm{a}$ & $210.98 \mathrm{a}$ & $252.84 \mathrm{a}$ & 159.65 \\
\hline S14 & $112.70 \mathrm{a}$ & $133.41 \mathrm{a}$ & $136.67 \mathrm{a}$ & $161.18 \mathrm{a}$ & $161.03 \mathrm{a}$ & $171.83 \mathrm{ab}$ & $191.49 \mathrm{a}$ & $208.21 \mathrm{~b}$ & 159.56 \\
\hline $\mathrm{S} 15$ & $110.73 \mathrm{a}$ & $127.28 \mathrm{ab}$ & $132.87 \mathrm{ab}$ & $157.46 \mathrm{a}$ & $159.92 \mathrm{a}$ & $167.19 \mathrm{abc}$ & $179.45 \mathrm{ab}$ & $199.51 \mathrm{bc}$ & 154.30 \\
\hline Means & 90.50 & 113.18 & 117.78 & 143.71 & 148.72 & 160.03 & 176.32 & 198.50 & \\
\hline \multicolumn{10}{|c|}{$\mathrm{CV}(\%)=12$} \\
\hline & \multicolumn{9}{|c|}{ Light seeds -50 seeds } \\
\hline$\overline{\mathrm{S} 11}$ & $68.70 \mathrm{a}$ & $90.37 \mathrm{a}$ & $99.20 \mathrm{a}$ & $118.37 \mathrm{a}$ & $121.83 \mathrm{a}$ & $127.24 \mathrm{c}$ & $135.10 \mathrm{c}$ & $154.97 \mathrm{c}$ & 114.47 \\
\hline S12 & $75.83 \mathrm{a}$ & $98.05 \mathrm{a}$ & $110.70 \mathrm{a}$ & $122.34 \mathrm{a}$ & $130.73 \mathrm{a}$ & $138.26 \mathrm{c}$ & $156.78 \mathrm{c}$ & $184.18 \mathrm{c}$ & 127.10 \\
\hline $\mathrm{S} 13$ & $79.36 \mathrm{a}$ & $94.61 \mathrm{a}$ & $102.45 \mathrm{a}$ & $138.46 \mathrm{a}$ & $148.66 \mathrm{a}$ & $166.89 \mathrm{bc}$ & $210.28 \mathrm{~b}$ & $278.35 \mathrm{~b}$ & 152.38 \\
\hline S14 & $85.15 \mathrm{a}$ & $88.28 \mathrm{a}$ & $94.01 \mathrm{a}$ & $118.33 \mathrm{a}$ & $132.64 \mathrm{a}$ & $195.35 \mathrm{ab}$ & $312.30 \mathrm{a}$ & $451.52 \mathrm{a}$ & 184.69 \\
\hline $\mathrm{S} 15$ & $81.81 \mathrm{a}$ & $95.49 \mathrm{a}$ & $101.91 \mathrm{a}$ & $126.56 \mathrm{a}$ & $161.37 \mathrm{a}$ & $218.60 \mathrm{a}$ & $312.28 \mathrm{a}$ & $435.83 \mathrm{a}$ & 191.73 \\
\hline Means & 78.17 & 93.16 & 101.65 & 124.81 & 139.04 & 169.26 & 225.34 & 300.97 & \\
\hline \multicolumn{10}{|c|}{$\mathrm{CV}(\%)=14$} \\
\hline & \multicolumn{9}{|c|}{ Dark seeds -50 seeds } \\
\hline$\overline{\mathrm{S} 11}$ & $60.25 \mathrm{a}$ & $73.84 \mathrm{a}$ & $82.61 \mathrm{a}$ & $104.06 \mathrm{a}$ & $110.26 \mathrm{~b}$ & $122.73 \mathrm{c}$ & $138.93 \mathrm{~d}$ & $165.72 \mathrm{c}$ & 107.30 \\
\hline S12 & $67.87 \mathrm{a}$ & $92.81 \mathrm{a}$ & $99.11 \mathrm{a}$ & $118.57 \mathrm{a}$ & $126.24 \mathrm{ab}$ & $130.53 \mathrm{c}$ & $145.20 \mathrm{~cd}$ & $178.54 \mathrm{c}$ & 119.85 \\
\hline $\mathrm{S} 13$ & $90.87 \mathrm{a}$ & $99.75 \mathrm{a}$ & $108.12 \mathrm{a}$ & $144.35 \mathrm{a}$ & $175.12 \mathrm{a}$ & $227.23 \mathrm{a}$ & $298.42 \mathrm{a}$ & $376.99 \mathrm{a}$ & 190.10 \\
\hline S14 & $95.93 \mathrm{a}$ & $112.35 \mathrm{a}$ & $118.48 \mathrm{a}$ & $143.26 \mathrm{a}$ & $157.48 \mathrm{ab}$ & $171.04 \mathrm{bc}$ & $193.91 \mathrm{bc}$ & $216.36 \mathrm{bc}$ & 151.10 \\
\hline $\mathrm{S} 15$ & $91.69 \mathrm{a}$ & $104.38 \mathrm{a}$ & $115.45 \mathrm{a}$ & $152.16 \mathrm{a}$ & $172.13 \mathrm{a}$ & $187.36 \mathrm{ab}$ & $205.72 \mathrm{~b}$ & $235.38 \mathrm{~b}$ & 158.03 \\
\hline Means & 81.32 & 96.62 & 104.75 & 132.48 & 148.24 & 167.77 & 196.43 & 234.59 & \\
\hline
\end{tabular}

Means followed by the same lowercase letter in the column for each seed color and sample size did not differ between each other a $5 \%$ probability by the Tukey test.

Médias seguidas pela mesma letra minúscula na coluna, para cada coloração de sementes e tamanho de amostra, não diferem entre si a $5 \%$ de probabilidade pelo teste de Tukey.

For dark colored seeds, only the use of 50 seeds differentiated sub-lots after 48 hours. The use of 25 seeds showed differences after only 2 hours. Nevertheless, in both conditions, seeds from sieves 11 and 12 leached the least, and sieve 13 seeds showed the highest values of EC. In general, seeds from sieves 14 and 15 showed intermediate behavior. The first count of germination test showed that the seeds retained in sieve 13 (dark) showed lower performance and agreed with those obtained by the EC test after 24 hours of soaking. The seeds retained in sieves 11 and 12 were vigorous throughout the EC test even though they did not have high values in the first count of germination. They did not differ from those retained in sieve 14 with better physiological quality.

There was an increase in the quantity of exudates released by $P$. moniliformis Benth. seeds with increasing soaking period. This can be observed by regression 
equation estimators of electrical conductivity for the different sub-lots according to the soaking period with 25 or 50 seeds per replicate (Figure 1).
With 25 light colored seeds (Figure 1A), those retained in sieves 13,14 and 15 showed higher increases in the amount of exudates throughout the evaluation

25 seeds

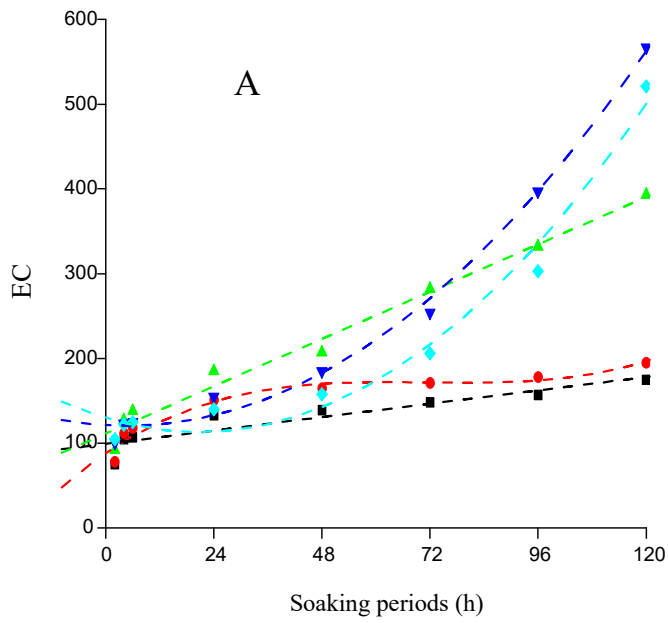

- $\mathrm{S} 11=99.8322+0.6566 \mathrm{x}$

$\begin{array}{ll}\mathrm{S} 11=99.8322+0.6566 \mathrm{x} & \mathrm{R}^{2}=0.84 \\ \mathrm{~S} 12=88.8537+3.6359 \mathrm{x}-0.05187 \mathrm{x}^{2}+0.0002422 \mathrm{x}^{3} & \mathrm{R}^{2}=0.95\end{array}$ $\mathrm{S} 13=112.1466+2.3214 \mathrm{x}$

S14 $=121.8350-0.3189 \mathrm{x}+0.03329 \mathrm{x}^{2}$ $\mathrm{S} 15=130.4990-1.6365 \mathrm{x}+0.03933 \mathrm{x}^{2}$
$R^{2}=0.98$ $\mathrm{R}^{2}=0.98$
$\mathrm{R}^{2}=0.99$ $\mathrm{R}^{2}=0.99$
$\mathrm{R}^{2}=0.97$

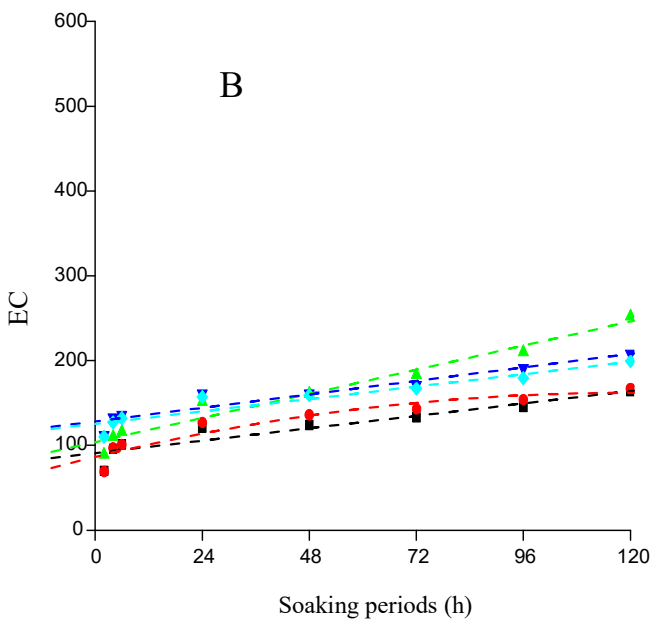

$\mathrm{S} 11=81.0921+2.2030 \mathrm{x}-0.03235 \mathrm{x}^{2}+0.0001661 \mathrm{x}^{3} \quad \mathrm{R}^{2}=0.92$ $\mathrm{S} 12=86.6608+1.2879 \mathrm{x}-0.005507 \mathrm{x}^{2} \quad \mathrm{R}^{2}=0.90$ $\begin{array}{ll}\mathrm{S} 12=86.6608+1.2879 \mathrm{x}-0.005507 \mathrm{x}^{2} & \mathrm{R}^{2}=0.90 \\ \mathrm{~S} 13=104.4706+1.1868 \mathrm{x} & \mathrm{R}^{2}=0.96\end{array}$

S1 $=104.4706+1.1868 \mathrm{x}$

$\mathrm{S} 15=126.0003+0.6087 \mathrm{x}$ $\mathrm{R}^{2}=0.91$ $\mathrm{R}^{2}=0.91$
$\mathrm{R}^{2}=0.89$

50 seeds
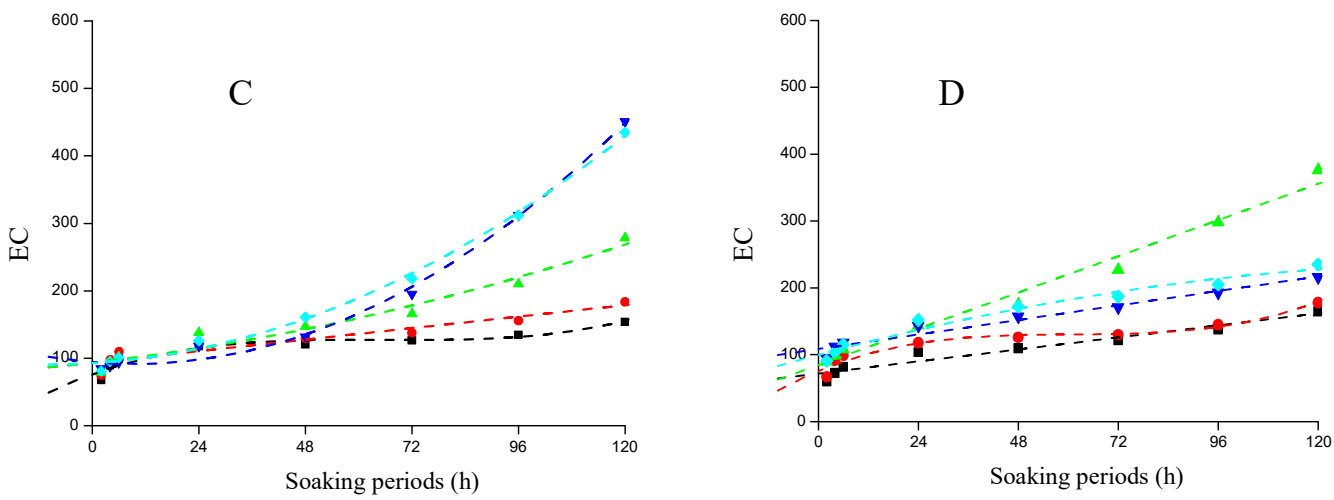

$\mathrm{S} 11=76.8575+2.4095 \mathrm{x}-0.03748 \mathrm{x}^{2}+0.000191 \mathrm{x}^{3}$

$\mathrm{S} 12=94.1106+0.7094 \mathrm{x}$

$\mathrm{S} 13=93.6891+0.7654 \mathrm{x}+0.0057907 \mathrm{x}^{2}$

$\mathrm{S} 14=94.3259-0.5433 \mathrm{x}+0.029150 \mathrm{x}^{2}$

$\mathrm{S} 15=93.4643+0.3953 \mathrm{x}+0.020153 \mathrm{x}^{2}$

$\mathrm{R}^{2}=0.93$

$\mathrm{R}^{2}=0.90$

$\mathrm{R}^{2}=0.96$

$\mathrm{R}^{2}=0.99$

$\mathrm{R}^{2}=0.99$

Figure 1 - Electrical conductivity $\left(\mathrm{EC}, \mu \mathrm{s} \mathrm{cm}^{-1} \mathrm{~g}^{-1}\right.$ ) of Piptadenia moniliformis Benth. seeds, using 25 and 50 seeds per replication, soaked in $75 \mathrm{ml}$ of distilled water at $25^{\circ} \mathrm{C}$ for different soaking periods. S11, S12, S13, S14 and S15 are seeds retained in sieves of sizes $11,12,13,14$ and 15 , respectively. Color: light (A, C) dark (B, D).

Figura 1 - Condutividade elétrica $\left(\mu \mathrm{S} \mathrm{cm}^{-1} \mathrm{~g}^{-1}\right)$ de sementes de Piptadenia moniliformis Benth., utilizando 25 e 50 sementes por repetição, embebidas em $75 \mathrm{~mL}$ de água destilada a $25{ }^{\circ} \mathrm{C}$, por diferentes períodos de embebição. S11, S12, S13, S14 e S15: respectivamente, sementes retidas nas peneiras de tamanho 11, 12, 13, 14 e 15. Coloração: clara $(A, C)$ escura $(B, D)$. 
period. At 120 hours of soaking, these values were $393.72,567.88$ and $521.72 \mu \mathrm{S} \mathrm{cm}^{-1} \mathrm{~g}^{-1}$, respectively, versus 175.06 and $195.10 \mu \mathrm{S} \mathrm{cm}^{-1} \mathrm{~g}^{-1}$ in seeds from sieves 11 and 12 , respectively. The tendency was similar with 50 seeds (Figures 1C and 1D). However, the EC values were lower than those observed with 25 light seeds as well as dark seeds from sieve 11 .

For dark colored seeds of both quantities (Figures $1 \mathrm{~B}$ and $1 \mathrm{D})$, the pattern of leaching was different from that observed for light colored seeds (Figures 1A, 1C). With 25 seeds (Figure 1B), all size classes had nearly identical behavior. There were small increases in the amount of exudates over 120 hours of soaking. The values recorded for the seeds in sieves $11,12,13,14$ and 15 after 120 hours were 164.90, 167.07, 252.84, 208.21, and $199.51 \mu \mathrm{S} \mathrm{cm}^{-1} \mathrm{~g}^{-1}$, respectively.

For dark colored seeds with 50 seeds per replication (Figure 1D), the values of EC after 120 hours of soaking were $165.72,178.54,376.99,216.37$, and $235.38 \mu \mathrm{S} \mathrm{cm}^{-}$ ${ }^{1} \mathrm{~g}^{-1}$, respectively, for seeds from sieves $11,12,13,14$ and 15 . With the exception of seeds from sieve 13 (less vigor), the others showed a similar behavior. The seeds retained in sieves 11 and 12 leached the least and are considered the most vigorous. Using the results of the first count of germination (Table 1), the dark seeds retained in sieve 13 had the least physiological potential despite not being different from those in sieves 11 , 12 and 15 . This agrees with the EC test, which demonstrated the poor quality of this sub-lot. The IGS and germination data show that the dark colored sublots do not differ.

\section{DISCUSSION}

Seed lots should have a consistent water content to standardize evaluations and obtain normalized results for the electrical conductivity test (VIEIRA, 1994). In this study there was a range of $2 \%$ variation in water content between sub-lots. One of the reasons for this variation is the fact that the seeds from angico-debezerro were collected from different mother trees that may have produced seeds with different degrees of moisture due to variation in the flowering and harvesting period. Thus, variations persisted even when separating the seeds by size and color.

According to Vieira (1994), the uniformity of water content can enable the identification of lots with different levels of vigor. Several authors have found a significant increase in EC for water contents below 11\%. Generally, soybean water content should be between 11 and $17 \%$ (AOSA, 1983), otherwise there is a significant increase in EC results. Gonçalves et al. (2008) worked with seeds from Guazuma ulmifolia Lam. and found water content varying between 9.6 and 10.2\%; Dalbergia nigra Allemão ex Benth seeds had water content that varied from 9.36 to $10.61 \%$ (MARQUES et al., 2002b). However, the values of the EC did not differ much and can be compared.

The EC test is rarely used for forest seeds. Marques et al. (2002b) found that this test cannot always detect differences between lots. On the other hand, the test is used in several studies with different botanical families. These involved the electrical conductivity test in a promising manner. Examples include Cherobini et al. (2008) with seeds from Cedrela fissilis Vell. (Meliaceae); Dutra et al. (2007) with seeds from Senna siamea (Lam.) H.S. Irwin \& Barneby (Caesalpinioideae); Gonçalves et al. (2008) with Guazuma ulmifolia Lam. (Sterculiaceae); Marques et al. (2002a) with Dalbergia nigra (Vell.) Fr. All. ex. Benth (Fabaceae); and Santos and Paula (2005) with seeds from Sebastiania commersoniana (Baill) Smith Downs (Euphorbiaceae). It is difficult to compare our study to the literature because the species are distinct and belong to different families and different ecological groups (CARVALHO, 2003, 2006, 2008). They also exhibit differences in chemical composition and types of seed reserves. This results in different leaching amounts and patterns detected in the electrical conductivity test.

For example, Borges et al. (1990) observed that the viability of seeds from Cedrela fissilis submitted to accelerated aging are somehow related to the carbohydrate reserve and with the membrane permeability, but not with lipid reserves. More specifically, some conclusions were found for Dalbergia nigra a species in which there are several studies regarding changes in chemical composition during the germination process. First, the variation in the amount of protein (albumin) in embryos was not correlated with seed germination or electrical conductivity of osmoconditioned seeds (BORGES; BORGES, 1996). Second, the degradation of the seeds is not necessarily associated with changes in lipids nor in soluble or cell wall sugars (BORGES et al., 2000). Third, two Dalbergia nigra seed lots had lipid contents of 23.9 and $25.2 \%$, and the quality of the lot was not related to the lipids. However, the 
physiological quality and the water content of the lot influenced changes in soluble carbohydrates, starch, proteins and lipids in cotyledons. A reduction in starch content in cotyledons was prominent in the less vigorous lot (ATAIDE et al., 2013).

Piptadenia comunis Benth. seeds submitted to accelerated aging did not present changes in electrical conductivity and protein content, but had reductions in lipid content (BORGES et al., 1992). According to Bonner (1998), one of the biggest difficulties in standardizing the electrical conductivity test for forest seeds is the large variability within a seed lot. Even in Piptadenia comunis, which is in the same genus as the species in this study, the seeds are produced through open pollination between individuals without any degree of domestication and/or improvement. This generates a large diversity of genotypes with variability in their chemical constitution as well as differences in the degree of maturation. This is reflected in the electrical conductivity data.

More leachates were seen in the light colored seeds than dark colored seeds. This may be related to the degree of seed maturation. It is possible that light colored seeds have not reached their complete physiological maturity. Powel (1986) cited by Araujo et al. (2006) found that as the seed develops and approaches physiological maturity, there is a structural reorganization of the cell membrane. In this case, the seed has low EC values. The opposite occurs when the seeds are not yet fully formed. In this regard, Flores et al. (2014) observed that light colored seeds from Melanoxylon brauna Schott. had an inferior physiological quality to dark colored seeds. The results were correlated to the degree of maturity in the seeds.

The EC test for $P$. monilifomis seeds differentiated the sub-lots for a relatively long soaking period. This was partially consistent with the results of the initial characterization in most tested sub-lots. The overall goal of the test is to differentiate seed lots. This should ideally be fast and specific to guide horticulture.

The electrical conductivity test is not suitable for evaluating the vigor of $P$. moniliformis Benth seeds. It took a long time and the results were inconsistent. The electrical conductivity test conducted by Gonzales et al. (2009) with Albizia hassleri (Chodat) Burkart seeds was also not suitable in discriminating physiological quality of seeds from different mother trees. However, for Solanum sessilifolium Dunal seeds, a soaking period of 2 hours was sufficient to evaluate physiological quality in seeds using the electrical conductivity test (PEREIRA; MARTINS FILHO, 2012). The efficiency of the electrical conductivity test was also observed in evaluating physiological quality of Dalbergia nigra seeds under different temperatures (MATOS et al., 2015).

There was an increase in the amount of exudates released from $P$. moniliformis Benth. seeds with an increase in soaking period (Figure 1). This agrees with Marques et al. (2002a, 2002b) who used seeds from Dalbergia nigra (Vell.) Fr. All. Ex. Benth, Santos and Paula (2005) with seeds from Sebastiania commersoniana (Bail) Smith Downs, and Dutra et al. (2007) with seeds from Senna siamea (Lam.) H.S. Irwin \& Barneby. This was true regardless of incubation temperature and water volume.

These results differ from Vanzolini and Nakagawa (2005) who found an increase in electrical conductivity values in seeds from Arachys hypogaea L. when using 50 seeds compared to the use of 25 seeds per replication. The authors show that this occurred because of the increase in number of seeds for the same volume of water. There was a higher concentration of leachates in the solution, and this resulted in higher EC values. It is possible that in this study, the exudates present in the solution were volatilized. This could have decreased the measured values. The EC results confirmed, in part, the results provided by the first count that indicated the seeds in sieve 13 (dark color) had a lower quality. Seeds in sieve 14 were more vigorous, and this did not differ from sub-lots of size 11,12 , and 15 with a soaking time of 72 hours using 50 seeds.

One of the factors interfering with the EC test is seed size (CARPI, 2005). Here, the smaller seeds, in general, had the lowest EC values. In the literature, varying results are found in terms of the effect of this characteristic on the EC values. Vanzolini and Nakagawa (2005) found that this influence is not always confirmed. In beans of Coffea arabica L., Prete (1992) and Malta et al. (2005) found that smaller seeds had higher EC values. Vanzolini and Nakagawa (1997) and Vanzolini and Nakagawa (2005) observed similar results for Arachis hypogaea L. seeds.

In using the electrical conductivity test, Aosa (2002) cited by Vidigal et al. (2008), recommends four replications of 25 seeds. Loeffler et al. (1988) suggests using 50

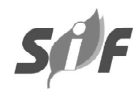

Revista Árvore, Viçosa-MG, v.40, n.5, p.855-866, 2016 
seeds to reduce the coefficient of variation between samples. Among the factors that influence the EC test results, the number of seeds per replicate is one of these factors. To adapt the EC methodology, some studies evaluated different numbers of seeds, and the responses are highly variable according to the species or between cultivars of the same species. In tomato cultivars, SÁ (1999) observed that the number of seeds did not affect the EC values. For seeds from Sebastiania commersoniana (Bail) Smith Downs, Santos and Paula (2005) recommended using 75 seeds soaked in $75 \mathrm{~mL}$ of water for 24 hours at $25^{\circ} \mathrm{C}$. However, Gaspar and Nakagawa (2002) used Pennisetum glaucum L. seeds and concluded that the best combination for achieving the EC test was 100 seeds in $100 \mathrm{~mL}$ of distilled water at $25^{\circ} \mathrm{C}$ for 24 hours.

With P. moniliformis Benth. seeds we found discrepancies between the data obtained during the initial characterization and data from the EC test regardless of seed count ( 25 or 50 seeds per test). On the other hand, it is important to note that this species can go dormant due to the impermeability of the seed coat to water. Thus, the seeds can have different degrees of dormancy in some sub-lots. All the sub-lots were subjected to the same scarification, and this may explain the reverse values seen in the EC testing. Consequently, it is possible that smaller seeds have greater impermeability of the tegument as demonstrated by Souza et al. (1996), Lin (1999), and Nakagawa and Cavariani (2005). Therefore, when submitted to the same pre-germination treatment, smaller seeds leached less than larger seeds. Consequently, the result is that the EC test may not be suitable for testing seed dormancy by tegument impermeability to water.

\section{CONCLUSION}

The electrical conductivity test using 25 and 50 seeds per replicate, soaked in $75 \mathrm{~mL}$ of distilled water at $25^{\circ} \mathrm{C}$ for different periods of time, is not adequate to evaluate the physiological quality of $\mathbf{P}$. moniliformis Benth. seed sub-lots classified by color and size.

\section{REFERENCES}

ASSOCIATION OF OFFICIAL SEED ANALYSIS AOSA. Seed vigour handbook. In: The handbook of seed testing. East Lansing: 1983.88 p. (Contribuition, 32).

Revista Árvore, Viçosa-MG, v.40, n.5, p.855-866, 2016
ARAÚJO, E.F.; ARAÚJO, R.F.; SOFIATTI, V.; SILVA, R.F. Qualidade fisiológica de sementes de milho-doce colhidas em diferentes épocas. Bragantia, v.65, n.4, p.687-692, 2006.

ARAÚJO, R.F.; ZONTA, J.B.; ARAÚJO, E.F.; HEBERLE, E.; ZONTA, F.M.G. Teste de condutividade elétrica para sementes de feijãomungo-verde. Revista Brasileira de Sementes, v.33, n.1, p.123-130, 2011.

ATAÍDE, G.M.; BORGES, E.E.L.E.; GONCALVES, J.F.C.; GUIMARAES, V.M.; FLORES, A.V.; BICALHO, E.M. Alterations in seed reserves of Dalbergia nigra ((Vell.) Fr All. ex Benth.) during hydration. Journal of Seed Science, v.35, p.56-63, 2013.

BARBOSA, R.M.; LEÃO, E.F.; CAPRIO, C.H.; VIEIRA, R.D. Teste de condutividade elétrica em sementes de maracujazeiro-amarelo. Revista Brasileira de Fruticultura, v. 34, n.2, p.646-651, 2012.

BONNER, F.T. Testing tree seeds for vigor: a review. Seed Technology, v.20. n.1, p.5-17, 1998.

BORGES, E.E.L.; CASTRO, J.L.; BORGES, R.C.G. Alterações fisiológicas em sementes de jacaré (Piptadenia communis) submetidas ao envelhecimento precoce. Revista Brasileira de Sementes, v.14, p.9-12, 1992.

BORGES, E.E.L.; BORGES, R.C.G. Modificações fisiológica em sementes osmocondicionadas de jacarandá-da-bahia (Dalbergia nigra (Vell.)Fr. All.). Revista Árvore, v.20, p.147-154, 1996.

BORGES, E.E.L.; BORGES, R.C.G.; CASTRO, J.L. Avaliação fisiológicas de sementes de cedro submetidas ao envelhecimento precoce. Revista Brasileira de Sementes, v.121, p.56-62, 1990.

BORGES, E.E.L.; BORGES, R.C.G.; BUCKRIDGE, M.S. Alterações nas composições de carboidratos e de ácidos graxos em sementes de Jacarandá-daBahia osmocondicionadas. Revista Brasileira de Fisiologia Vegetal, v.12, n.1, p.1-10, 2000.

BRASIL. Ministério da Agricultura e Reforma Agrária. Regras para análise de sementes. Brasília: SNDA/DNDV CLAV, 2009. 365p. 
CARPI, V.A.F. Avaliação do potencial fisiológico de sementes de rabanete (Raphanus sativus L.). 2005. 77f. Dissertação (Mestrado em Agronomia) - Escola Superior de Agricultura “Luiz de Queiroz”, Universidade de São Paulo, Piracicaba, 2005.

CARVALHO, P.E.R. Espécies arbóreas brasileiras. Brasília: Embrapa Informação Tecnológica, 2003. v.1.1039p.

CARVALHO, P.E.R. Espécies arbóreas brasileiras. Brasília: Embrapa Informação Tecnológica, 2006. v.2. 627p.

CARVALHO, P.E.R. Espécies arbóreas brasileiras. Brasília: Embrapa Informação Tecnológica, 2008. v.3. 593p.

CHEROBINI, E.A.I.; MUNIZ, M.F. B.; BLUME, E. Avaliação da qualidade de sementes e mudas de cedro. Ciência Florestal, v.18, n.1, p.65-73, 2008 .

CUSTÓDIO, C.C. Testes rápidos para avaliação do vigor de sementes: uma revisão. Colloquium Agrariae, v.1, n.1, p.29-41, 2005.

DUTRA, A.S.; MEDEIROS-FILHO, S.; DINIZ, F.O. Teste de condutividade elétrica em sementes de Senna siamea (Lam.) H.S. Irwin e Barneby.

Revista Ciência Agronômica, v.38, n.3, p.280-285, 2007.

FLORES, A.V.; BORGES, E.E.L.; GONÇALVES, J.F.C.; GUIMARÃES, V.M.; ATAIDE, G.M.; BARROS, D.P.; PEREIRA, M.D. Efeito do substrato, cor e tamanho de sementes na germinação e vigor de Melanoxylon brauna. Pesquisa Florestal Brasileira, v.34, n.78, p.141-147, 2014.

GASPAR, C.M.; NAKAGAWA, J. Teste de condutividade elétrica em função do número de sementes e da quantidade de água para sementes de milheto. Revista Brasileira de Sementes, v.24, n.2, p.70-76, 2002.

GONÇALVES, E.P.; PAULA, R.C.; DEMATTÊ, M.E.S.P. Testes de vigor em sementes de Guazuma ulmifolia Lam. Semina, v.29, n.2, p.265-276, 2008.
GONZALES, J.L.S.; PAULA, R.C.; VALERI, S.V. Teste de condutividade elétrica em sementes de Albizia hassleri (Chodat) Burkart. FabaceaeMimosoideae. Revista Árvore, v.33, n.4, p.625-634, 2009.

HAMPTON, J.G.; COOLBEAR, P. Potential versus actual seed perfomance. Can vigour testing provide an answer? Seed Science and Technology, v. 18, n.1, p.215-228, 1990.

LIN, S.S. Quebra de dormência de sementes de feijão-mungo. Pesquisa Agropecuária Brasileira, v.34, n.6, p.1081-1086, 1999.

LOEFFLER, T. M.; TEKRONY, D. M.; EGLI, B. D. The bulk conductivity test as on indicator of soybean seed quality. Journal of Seed Technology, v.12, p.37-53, 1988.

MAGUIRE, J.D. Speed of germination aid selection and evaluation for seedling emergence and vigour. Crop Science, v.2, p.176-177, 1962.

MALTA, M.R.; PEREIRA, R.G.F.A.; CHAGAS, S.J.R. Condutividade elétrica e lixiviação de potássio do exsudato de grãos de café: alguns fatores que podem influenciar essas avaliações. Ciência Agrotécnica, v.29, n.5, p.1015-1020, 2005.

MARCOS FILHO, J. Fisiologia de sementes de plantas cultivadas. Piracicaba: FEALQ, 2005. 495p.

MARQUES, M.A.; PAULA, R.C.; RODRIGUES, T.J.D. Adequação do teste de condutividade elétrica para determinar a qualidade fisiológica de sementes de jacarandá-da-bahia (Dalbergia nigra (Vell.) Fr. All. ex. Benth). Revista

Brasileira de Sementes, v.24, n.1, p.271$278,2002 b$

MARQUES, M.A.; PAULA, R.C.; RODRIGUES, T.J.D. Efeito do número de sementes e do volume de água na condutividade elétrica de sementes de Dalbergia nigra (Vell.) Fr. All. Ex. Benth. Revista Brasileira de Sementes, v.24, n. 1, p.254-262, 2002a.

MATOS, A.C.B.; BORGES, E.E.L.; SILVA, L.J. Fisiologia da germinação de sementes de Dalbergia nigra (Vell.) Allemão ex Benth. sob diferentes temperaturas e tempos de exposição. Revista Árvore, v.39, n.1, p.115-125, 2015.

Revista Árvore, Viçosa-MG, v.40, n.5, p.855-866, 2016 
NAKAGAWA, J.; CAVARIANI, C. Efeito do tamanho na germinação de sementes de mucuna-preta. Científica, v.33, n.2, p.213-217, 2005.

PEREIRA, M.D.; MARTINS FILHO, S. Adequação da metodologia do teste de condutividade elétrica para sementes de cubiu (Solanum sessiliflorum DUNAL). Revista Agrarian, v.5, n.16, p.93-98, 2012.

PERRY, D.A. Report of the vigour test commitee 1977-1980. Seed Science and

Technology, v.9, n.1, p.115-126, 1981.

PIÑA-RODRIGUES, F.C.M. Manual de análise de sementes florestais.

Campinas: Fundação Cargill, 1988. 99p.

PIÑA-RODRIGUES, F.C.M.; VALENTINI, S.R.T. Aplicação do teste de vigor em sementes. In: SILVA, A.; PIÑA-RODRIGUES, F.C.M.; FiglioliA, M.B. (Coord.). Manual técnico de sementes florestais. São Paulo: Instituto Florestal, 1995. p.74-84.

PINHO, D.S.; BORGES, E.E.L.; CORTE, V.B.; NASSER, L.C.B. Avaliação da qualidade fisiológica de sementes de Anadenanthera peregrina (L.) Speg. durante o armazenamento. Revista Árvore, v.33, n.1, p.27-33, 2009.

PRETE, C.E.C. Condutividade elétrica do exsudato de grãos de café (Coffea arabica L.) e sua relação com a qualidade da bebida. 1992. $125 \mathrm{f}$. Tese (Doutorado em Agronomia/Fitotecnia) - Escola Superior de Agricultura "Luiz de Queiroz", Universidade de São Paulo, Piracicaba, 1992.

SÁ, M.E. Condutividade elétrica em sementes de tomate (Lycopersicom lycopersicum L.).

Scientia Agricola, v.56, n.1, p.13-19, 1999.

SANTOS, S.R.G.; PAULA, R.C. Teste de condutividade elétrica para avaliação da qualidade fisiológica de sementes de Sebastiania commersoniana (BAIL) Smith
Downs - EUPHORBIACEAE. Revista

Brasileira de Sementes, v.27, n.2, p.136-145, 2005.

SOUZA, F.H.D.; MARCOS FILHO, J.; NOGUEIRA, M.C.S. Características físicas das sementes de Calopogonium mucunoides Desv. associadas à qualidade fisiológica e ao padrão de absorção de água. I. Tamanho. Revista Brasileira de Sementes, v.18, n.1, p.33-40, 1996.

TORRES, S.B. Envelhecimento acelerado em sementes de pimenta-malagueta Capsicum frutescens L.). Revista Ciência Agronômica, v.36, n.1, p.98-104, 2005.

TORRES, S.B. Métodos para avaliação do potencial fisiológico de sementes de melão. 2002. 103f. Tese (Doutorado em Agronomia) - Escola Superior de Agricultura "Luiz de Queiroz”, Universidade de São Paulo, Piracicaba, 2002.

VANZOLINI, S.; NAKAGAWA, J. Teste de condutividade elétrica em sementes de amendoim: efeitos da temperatura e do período de embebição. Revista Brasileira de Sementes, v.21, n.1, p.41-45, 1997.

VANZOLINI, S.; NAKAGAWA, J. Teste de condutividade elétrica em sementes de amendoim. Revista Brasileira de Sementes, v.27, n.2, p.151-158, 2005.

VIDIGAL, D.S.; LIMA, J.S.; BHERING, M.C.; DIAS, D.C.F.S. Teste de condutividade elétrica para semente de pimenta. Revista Brasileira de Sementes, v.30, n.1, p.168-174, 2008.

VIEIRA, R.D. Teste de condutividade elétrica. In: VIEIRA, R.D.; CARVALHO, N.M. (Ed.). Testes de vigor em sementes. Jaboticabal: FUNEP, 1994. p.103-132.

VIEIRA, R.D.; KRZYZANOWSKI, F.C. Teste de condutividade elétrica. In: KRZYZANOWSKI, F.C.; VIEIRA, R.D.; FRANÇA-NETO, J.B. (Ed.). Vigor de sementes: conceitos e testes. Brasília: ABRATES, 1999. p.1-26. 